50 The Journal of Madhyabindu Multiple Campus, Vol. 6, No. 1, 2021

\title{
CRITICAL DISCOURSE ANALYSIS OF MALALA YOUSAFZAI'S SPEECH ON SOCIAL AND EDUCATIONAL EMPOWERMENT OF WOMEN
}

\begin{abstract}
C. N. Sapkota *
Abstract

The present study analyzes the critical discourse analysis of Malala Yousafzai's speech delivered in the United Nations in July, 2013 from the perspective of social and educational women empowerment and especially it looks at how social power is legitimized by the specific leading entities. It examines the relationship of language, events, practices, socio-cultural structures and relations to understand how the texts are ideologically formed by the relations of power. The analysis was conducted following Fairclough'sthree-D model of Critical Discourse Analysis
\end{abstract}

Key words: Critical Discourse Analysis, women empowerment, socio-cultural practice, education

\section{Background of the study}

The present study aims to present the critical discourse analysis of the language used in Malala Yousufzai's speech delivered at the United Nations Youth Assembly in July 2013, from the perspective of social and educational empowerment perspectives of women.Human beings use language as a tool of communication. In communication, there is an interaction between speaker and listener. In such interaction, there is a tendency of the unequal power relationship between the speaker and listener. From the conversation, it can be seen that a member or group is dominant over another member or group. Such inequality and power in the use of language are analyzed in critical discourse analysis. Wodak (2001) emphasized that language is not power itself but power is gained in language by its use and powerful people make of it. Furthermore, Foucault (1972) believed that language plays a dominant role in reproducing and transforming power relations.

Discourse is related to speech patterns and usage of language. Foucault (1997) believes that discourse is embedded with socio-cultural practice. It means that the language used in speech and writing seems like a social practice that "implies a dialectical relationship between a particular discursive event and the situation(s), institution(s), and social structure(s) which frame it" (Fairclough \&Wodak, 1997, p. 258). Foucault (1997) further insists that discourse is the system of knowledge that informs the social activities that constitute power in modern society. In this case, critical discourse analysis tries to explore the socially transformative effects of discursive change. Van Dijk (2010) states that discourse is a complex communicative event in which the members of powerful groups, institutions, or leaders have more or less access to control over public discourse. He further explains that critical discourse analysis is crucial to create awareness about their role in society. So, discourse is produced by social interaction and influenced by social structure. Sipra and Rashid (2013) mentioned that discourses are influential and they produce and reproduce unequal power relations in the variety of ethnicities, ages, social classes, and professional groups. This speech is selected to show the relationship between language and power. This persuasive nature of speech motivates the audience

* Mr. Sapkota is Lecturer of Madhyabindu Multiple Campus and M. Phil. Scholar of NOU. 
through women's empowerment and the need for education for women. This is the subject that the researcher addresses using the method of critical discourse analysis.

Discourse analysis is defined as "the study of language in use" (Wetherell et al. 2001a, p. 3). The discourse analytic study of the speech is characterized by power relations concerning the way discourse is conceptualized. The approach of discourse analysis in this research is to examine the use of language that reconnects the instances of power relation and how discourse and power are manifested to women empowerment.

The speech is related to women's empowerment in society which is expressed through language and practice. Critical discourse analysis is related to social actions that identify how power hegemony and domination rise in society. Wodak and Chilton (2003) opine that discourse stands in a causal relationship to social action. Furthermore, Weiss and Wodak (2003) state critical discourse analysis as discursive reproduction of power abuse and consequences on social inequality.Discourses are expressed through language and behavior and the relationship between language and power. The researcher in this study analyzes how our society is being shaped by language, which in turn reflects existing power relationships.

Discourse practices are linked with the relative power of discourse participants. It is organized in a social setting in the producers, distributors and receivers act in particular roles. Such relationships are often characterized by the unequal distribution of power. Discourse is a culturally constructed representation of reality that constructs knowledge and governs through the production of categories of knowledge and assemblages of text. In doing so, it reproduces power and knowledge simultaneously. Gramsci (1971) believed that such power may enact hegemonically through naturalizing ideologies as common sense rather than sheer force. Discourse both written and oral mediated social action, doing ideological work by 'representing and constructing society' and "by reproducing unequal relations of power" (Wodak, 1996, p. 18). Thus, discourse serves identical and interpersonal functions.

\section{Research Questions}

a) How does the use of textual strategies reflect the views of women empowerment in the speech?

b) To what extent do the stylistic features represent the social and educational empowerment of women in the speech?

\section{Review of the Literature}

This section briefly reviews the existing theoretical literature and critical discourse analysis of Malala's speech. In this sense, discourse theory is directly concerned with human beings. It is not only conceived as knowledge as an internal agent but also gives a structured set of claims. Such discourse of claims or knowledge functions as a power relationship. As discourse is communicative practice, it is not concerned with the institutional setting within which it is implemented. The first part is concerned with critical discourse analysis, and the second, third and fourth parts are concerned with social empowerment, educational empowerment, and women empowerment respectively.

\section{Critical Discourse Analysis}

CDA was first developed by the Lancaster School of Linguists and the most dominant figure of CDA was Norman Fairclough. However, it was developed as an important approach to social theory when Karl Marx, Antonio Gramsci, Louis Althusser, Jurgen Habermas, and Michel Foucault used this approach in a socio-political context, examining ideologies and power relations. 


\section{The Journal of Madhyabindu Multiple Campus, Vol. 6, No. 1, 2021}

This article aims to identify some of the discursive constructions of Malala Yousafzai's speech considering in terms of social, educational and women empowerment power dynamics. Foucauldian discourse analysis of power, discourse, and subject to explore and critique the discursive resources deployed by the discourse of the speech.

CDA is a special approach to study in written and oral texts which emerge from critical linguistics, critical semiotics, and socio-politically conscious and oppositional ways of investigating language, discourse, and communication (Foucault, 1987). It is problem and issue-oriented to effectively study relevant social issues of inequalities. It does not only characterize a particular field but also explicitly critical approach, position, or stance of studying written or oral text. It is a multidisciplinary approach that studies social problems focusing on the relationship between discourse and society. Historically, CDA is a broad spectrum of critical studies in humanities and social sciences. All levels of dimensions of discourse, including grammar, rhetoric, speech acts, style, strategies, etc. fall under the study of discourse. CDA also focuses on relations of power, dominance, inequality, enacted dominance, and underlying ideologies in social theories (McHaul\& Grace, 2003). Not only this, but it also tries to formulate solidarity of dominated groups, developing counter-power and counter ideologies in practices of challenge and resistance. Discourse is not only limited to verbal action but also involves meaning, interpretation, and understanding. Public discourse may also affect the mind of others.

In the sense of Malala Yousafzai's speech, the discourse of power is analyzed as 'disciplinary power' for social service. Such power is away from the episodic exercise of power. Gaventa (2003) explains that power does not recognize negative, coercive, or repressive things but for the productive and positive force of the society. In this speech, discourse transmits and produces power that is a major source of social discipline.

Critical discourse studies observe "language as social practice" which means the use of the language according to the context is crucial (Fairclough \&Wodak, 1997, p. 5). In the English language speaking world discourse is used in both written and spoken texts (Gee, 2004, Schiffrin 1994, p. 7). It comprises "any forms of speech that may be used to manipulate the impression given to the audience" (Roffee, 2016, p. 134). Thus, the main concern of CDA is like the change of discourse, the ideas, facts, and knowledge is not constant or static. It is a powerful tool to show how the curriculum works, how social relations regulated and constructed, how it operates politically and how it positions in a society.

CDA concerns with the changes which are particularly taking place in contemporary social life. It is an "analysis of the dialectical relationships between semiotics (including language) and other elements of social practices" (Fairclough, 1992, p. 133). Such a semiotic social order is known as discourse. Discourses have various representations of social life such as everyday conversation, meeting of various types of organization, political and other forms of interviews. In this regard, the speech of Yusufzai is represented through discourse in social practices corresponding with various positions of social actors.

The discourse of Malala's speech is an institutionalized way of conversation and practice of power and knowledge. The knowledge of speech is an exercise of power. In this sense, Clark (2006) stated that power produces knowledge and it is an apparatus of knowledge and that knowledge becomes power. So, knowledge and power are embedded together. The power relation of speech manifests from the relationship of listener and hearer. Foucault (2007) mentions the assumption of power and knowledge as: 
It is therefore not a matter of describing what knowledge is and what power is and how one would repress the other or how the other would abuse the one rather, a nexus of knowledge power has to be described so that we can grasp what constitutes the acceptability of a system (p. 61).

So, this study analyzes the power as the knowledge that is generated by the discourse of speech in course of seeking information.

Fairclough also explains the three interconnected analytical discourse concerns: dominance, difference, and resistance. Dominance concerns identifying the dominant factors in genres, discourse, and style; difference concerns with the range of diversity and resistance denotes colonizing new domains. This research focuses upon the social problem which has the discursive aspect. This article uses academic sources to identify the sense of social context. In this regard, Fairclough (1992) believes that such a sense of major contemporary social problems arises from a broad perspective on social order ( $p$. 124). Among the two main discourses: internal relations and external relations, this study focuses on 'representation' which involves the description of people's ideas.

Critical discourse analysis is a critical perspective that integrates linguistic and social science. Ehclich and Romaniuk (2013) view critical discourse analysis as the discourse of social structure and social practices in a discursive dimension to see inequalities. Fairclough (2012) further clarifies that critical discourse analysis, as an approach connects some disciplines and theories to address social change. So critical discourse analysis examines discourse in a transdisciplinary way to bring in change and awareness toward social problems.

Critical discourse analysis is also the study of language and power. It means that discourse brings language use as a "representation of reproduction and negotiation of social power" (Sinaga, 2018, p. 59). Some components of language illustrate power in a particular discourse. The use of finite verbs, subjects, modality, and other various lexico-grammatical items are related to discourse. Such language properties are analyzed using CDA to find out how such discursive words can produce power. In this regard, Van Dijk (1993) revealed that researchers of critical discourse analysis mainly aim to discover the structures, strategies, or any other properties of the text to perform the role of dominance. Thus, language may imply the voice of a dominated group's power.

In the present study, the speech of Malala Yousufzai is considered as the resistance attribute for social, educational and women empowerment. She stands against Taliban rules and regulations of restriction on girl's education and equality of women in the social sector. These Taliban people impose extreme ideologies, so Malala Yousufzai creates another power through the speech against them. This speech tends to constitute women's empowerment, freedom of education, and women's participation in every field of life.

\section{Social empowerment}

Social empowerment enables and strengthens women's social relations and their position in society. Social empowerment addresses inequality and discrimination based on race, ethnicity, disability, religion, and gender. In this regard Mandal (2013) opined that empowerment is a multi-dimensional social process in which people gain control over their own lives. Furthermore, Antony (2006) considers that it is a multi-dimensional process that enables the individual or group to realize their full identity and power.

Sociologist Gangrade (2001) believed in women's empowerment as equal status, opportunity, and freedom to develop herself. Women are badly treated almost in every society. In the same vein, Srivastava (2001) emphasized empowering women 


\section{The Journal of Madhyabindu Multiple Campus, Vol. 6, No. 1, 2021}

socially, economically, and politically to break away the male domination and claim equality.

\section{Education empowerment}

Educational empowerment is vital for sociopolitical and economic transformation. Srivastava (2001) pointd out that educational empowerment helps women in growing their intellectual well-being and social horizons. Rao (2001) clarified that women need to be given compulsory and free education to make them aware of their rights and duties. Education creates awareness, self-confidence, and self-esteem to make people think critically and creatively. It expands social horizons, removes narrow mindedness, superstition and enhances fellow-feeling and tolerance.

Patel (2013) stressed empowerment to equip women economically and develop positive self-esteem to face the difficulties of life. Education encourages them to participate in decision-making, policy formulation, and implementation. Pathak (2003) argued that education empowerment allows women to understand their actual rights, freedom, and liberty. It lets them re-examine life critically and creatively.

To study Malala Yousafzai's speech delivered at the United Nations Youth Assembly in July 2013, on a women empowerment perspective, the researcher applied critical discourse analysis. Podesva and Sharma (2013) state that critical discourse demonstrates awareness of discursive nature and aspects. As a discourse, the speech of Malala was analyzed as to how power domination is as social practice.

\section{Women empowerment}

Empowerment is related to the action of raising the status of women. It is about equipping and nurturing women to enable them to make selfdetermining decisions that are created in society. The power around them limited their voice, freedom, equality, and pursuit of happiness. They cannot express their views and knowledge because they are not at the decision-making level and nobody wants to hear them. Universal Declaration of Human Rights (2015), states:

Everyone has the right to freedom of opinion and expression, this right includes freedom to hold opinions without interference and to seek, receive and impart information and ideas through any media and regardless of the frontier" (p. 40).

This right declaration is expected to empower all women in every sector of everyday life.

Empowerment gives chances to people to understand and realize self-authority and empower them to change positively in their life. Lazo (1993) agreed that empowerment creates awareness, changes insight, perception, and people can recognize the possibilities and chances better than they ever have. This present study tries to analyze empowerment as an equal right of women and the use of their competence as men to achieve their freedom.

Women empowerment is possible through educational access that increases their skills and critical thinking. Furthermore, it increases their knowledge and that enhances them to be able to know what happening around them. UNESCO and UNICEF (2010), supported that education is essential for the empowerment of women. Besides, it removes poverty, social injustice, and discrimination.

The present study, a critical discourse analysis of Malala's speech, analyzes the effectiveness of women's education for the development of a society. Women have the rights and capacity to show their performance in every society. So, they should be empowered through education. The social injustice in Malala Yousafzai's speech is related to how theTaliban treat women unequally. She does not comply with their ethos and advocates that every gender is equal. Women empowerment aims to create 
women's awareness, their rights, and their participation in social activities.

\section{Research Methodology}

The qualitative study of Malala Yousufzai's speech was analyzed by applying critical discourse analysis. It analyzed the syntactic organization, lexical representation, and power of speech in women's social and educational empowerment perspective. The textual/stylistic strategies, interpretation, expression, and representation of the speech focused on the social and educational empowerment of women. This study added the previous knowledge of speech based on linguistic choices, discursive practices, and women's social and educational empowerment. It also covered how certain linguistic structures help the speaker to establish her ideology.

The data were collected from the speech delivered by Malala Yousufzai at the United Nations Youth Assembly in July 2013. The speech reflected the struggle and fight against Taliban ethos of social and educational rights of women. She wants to empower women to get free, safe and quality access to education with her lived experience in her speech.

The study was based on the 3D model of Norman Fairclough (1992), who had proposed three aspects in his framework of critical discourse analysis: text, socio-cultural, and discursive practices. Text can be analyzed as political and socio-economic factors that influence the discursive practices of society. Fairclough (1989) clarified that this approach contributes to raising social consciousness in human beings through language. The theoretical framework is critical discourse analysis that analyzes the discourse critically and reveals the social practices like women's social and educational empowerment. The analytical parameter is only the language used in her speech. As this article is purely qualitative, the data are the only language used in Malala's speech as mentioned earlier,and as such no interaction and interview.

\section{Discussion and Analysis}

The research used the secondary data of Malala Yousufzai's speech which was analyzed and interpreted based on three aspects, analysis of linguistic choices or text, discourse practice, and socio-cultural practices. The critical discourse analysis focuses on the social injustice of women in the field of education, and social activities interpreting the text from a socio-cultural perspective.

\section{Text analysis}

Analysis of the text is the main pillar that is linked with the analysis of language. Such a critical way of language study raises consciousness of social and educational issues. Text analysis relates to the analysis of lexical choices, cohesion, stylistic features, and coherence that give a border knowledge of the socio-political perspective of the speaker.

Through her speech, Malala addresses women and girls who are major victims of terrorism and encouraged them to fight against the violence they encounter. Malala speaks for women's empowerment in every sector of life which is the ideology of discourse. This speech gives power to the audience on social and educational issues.

In her speech Malala Yousufzai shows her concerns about the empowerment of women, girls, and every child:

So, here I stand, one girl among many.

I speak not for myself, but all the boys and girls.

I raise my voice- not so that I can shout, but so that those without a voice can be heard. (Yousafzai, 2020,p. 4).

The first line represents Malala's determination not to remain silent. The second and third create pressure on the Taliban authority. For 


\section{The Journal of Madhyabindu Multiple Campus, Vol. 6, No. 1, 2021}

this reason, she wants to raise her voice with mental clauses. The phrase "one girl among many" encourages women to raise their voices unequivocally.

The textual metafunction, "and they were afraid of the power of education," shapes the ideology of women's empowerment. Similarly, "they were afraid of equality," and "they were afraid of the power of education," present the negative impact of Islam and intends to share her perspective that equality and education empower women to possess power and credibility.

Another strategy of women's empowerment in Malala's speech is the importance of education. Education brings awareness and awareness brings a change in society. She "wants schools and education," to shape the career of women and girls and empower them. She asserts, "...speak for our rights and ... bring change through our voice," to all the women not to be silent and raise their powerful voice. She encourages women to share their experiences and complaints by empowering themselves with the weapon of knowledge and showing their strength with "unity and togetherness"(Yousafzai, 2020, p. 4).

Throughout her speech, Malala repeats words or phrases to emphasize her issue.

We call upon all the world leaders....

We call upon all the government...

We call upon the developed nations...

We call upon all the communities...

(Yousafzai, 2020, p. 6)

The phrase "we call upon" repeated seven times, clearly indicates that these women aspire for equality without any discrimination based on gender or sex. Similarly, the phrase "we must not forget," repeated three times advocates the responsibilities of women to achieve their rights and freedom. Likewise, women's empowerment can be described when she says "let us shield ourselves with unity and togetherness"(Yousafzai, 2020, p. 5). This clause shows resistance through the action of protest. Throughout her speech, she persuades her female audience to be united to carry off their rights. The use of "let us" is an invitation to the women for their empowerment.

\section{Analyzing context}

Malala Yousafzai delivered this speech in July 2013 at the United Nations Youth Assembly. As a young girl, she defined the Taliban policy in Pakistan and advocated for the education and rights of women. She was shot by Taliban terrorists on 9 October 2012 . After 9 months from the date she was shot, Yousafzai delivered this speech to the United Nations. Later on, at the age of 17, in 2014 she won the Nobel peace prize. In her speech, she highlighted education, women's rights, and empowerment. Her prime motif in this speech is for the equality of women and empowerment through education. The women are considered socially, economically, and politically inferior. So, she wants to have equality for women on all grounds so that they could show their progress in every sector of their life. Malala tried to make aware of their rights and empower them.

Analysis of Discourse Practices and Social and Education Aspect of the Speech

Discourse practice is the second dimension of Fairclough's three-model aspects which consists of the production, circulation, and consumption of the text. In other words, analyzing the underlined structure pays attention to speech acts, coherence, and intertextuality or aspects of the text which connect with context (Blommaert \& Bulcaen, 2000). This dimension helps to operationalize the socially constitutive properties of discourse. Dremel and Matic (2014) believed that such conceptualizing of discourse focuses attention on the connection of part to whole, and micro to macro level, that helps to frame ideological process. 
Sipra and Rashid (2013) argued that discourse practices refer to the execution of social practices through discourse. Discourse is socially constructed and socio-cultural practices that provide an overview of the circumstances in which discourse is being constructed. The present study of Malala's speech is representative of the analysis of discourse practice and social or education aspects in three major areas such as genre, discourse analysis, and style as well as how they are interrelated to each other.

Genre analysis is the analysis of the text which is related to the lexical choices used in this speech with socio-cultural context. It also refers to the specific identification of patterns in the speech. The first part of the speech is a greeting to respect the listeners. Later on, in the opening section, she expresses thanks to the UN secretary for delivering a speech on social and educational issues faced by Pakistani women and girls. In this speech, Malala creates a relationship between patterns and the participants involved in the content of the speech. She has delivered this speech among 500 student representatives throughout the world. After the assassination attempt in October 2012, she fell in a coma for nine months but she decided to fight against Taliban terrorists. She defended the right of having education for women and empower them in every field of society.

The body part of her speech expressed the value of attending in United States Youth Assembly "I am here to speak up for the right of education of every child" which refers to the gloomy and desolate picture of Taliban children in the field of education. "Education for all the extremists especially the Taliban" refers to the sympathy shown to their children. Here, Malala is of the view that not only the Pakistani children but also the children of extremists are deprived of being independent educationally and socially. They are educationally and socially crippled in the name of religion. She uses the word education many times which indicates her stance on education for all without any discrimination.

Style is another aspect of critical discourse analysis. Sipra and Rashid (2013) stressed speech analysis where relational expressive values are interrelated. Relational valueis closely related to the relationship between the audience and the speaker. She expressed her view to the audience because she was one of the sufferers or oppressed ones in such a country where Taliban people never allow women to go to school for education. She uses the first-person pronouns 'I' and 'We' many times in her speech to show that the speaker is considered an oppressed member of the group along with other women and she wants to empower the girl children with the light of education. On the other hand, expressive value shows the expression of the personal experience of the speaker. The speaker Malala Yousafzai herself is the representative of women on whom assassination attempt was made by Taliban terrorists because of her educational and social activities to empower women socially and educationally. She has experienced the same deprivation and discrimination practices of society.

The speech represents the issue of empowerment particularly of the women who are socially and educationally disadvantaged. The representational value presents the particular sociocultural background to make the audience of the world conscious. This speech is different in the sense that it focuses on the socio-political conditions of the women as it revolves around the major idea of social and educational empowerment of women. Malala criticized the Taliban activities and challenged them that they could not stop their voice with bullets.

\section{Conclusion}

The women empowerment Malala delivered in her speech is the ideology of discourse. In her speech, she voices the suffering of women and tends 


\section{The Journal of Madhyabindu Multiple Campus, Vol. 6, No. 1, 2021}

to convince them to be strong. She also attracts the attention of the world at large, explaining the problem of women in Pakistan. Moreover, she encourages girls and women to exercise their rights. Through this speech, she depicts an ideology through language use that consists of a protest and demand for change. It identifies social evil that violates human rights. Malala addresses the women to tackle the obstacles and empower them educationally and socially. She has a mission on girl's and women's education, their rights, and temperance. She not only protests human rights violations but also focuses on women's awareness about their rights and pursuit of happiness. Women empowerment means to stand for their rights and dignity.

The ideology of women empowerment is elaborated through her struggle with Taliban terrorists. There is protest as well as her willingness to address girl's education and women's right in her speech. Constructively, she encourages women to conceptualize their power and ability. Besides, this speech also becomes an arena to counteract the activities of Taliban terrorists.

\section{References}

Antony, V. (2006). Education and employment: The key to women's empowerment. Kurukshetra, February, a Monthly Journal of Ministry of Rural Development, New Delhi.

Blommaert, J. (2005). Discourse. A critical introduction. Cambridge: Cambridge University Press.

Clark, R., \& Gieve, S. N. (2006). On the discursive construction of 'the Chinese learner'. Language, culture and curriculum, 19(1), 54-73.

Dremel, A., \& Matić, R. (2014). Discourse and/as Social Practice-the Analysis of the Problem of Resistance and Hegemony. Mediterranean Journal of Social Sciences, 5(22), 155.

Fairclough, N. (1992). Discourse and social change. Cambridge: Polity Press

Fairclough, N. (2001). Critical discourse analysis as a method in social scientific research. In R. Wodak \& M. Meyer (Ed.),Methods of Critical Discourse Analysis (pp. 121-138). London: Thousand Oaks.

Fairclough, N. (2012). Critical discourse analysis. International scientific research, 7: 1-36.

Foucault, M. (1987). Truth and power. In P. Rainbow (Ed.). The Foucault reader (pp.130-248). New York: Pantheon.

Foucault, M. (2007). The politics of Truth. In Lotringer, G. Semiotext.(pp.412-420). USA.

Gangrade, K.D. (2001). Gandhi and empowerment of women: Miles to go.In Promilla Kapur (Ed.), Empowering the Indian Women, (pp.132-142) New Delhi: Ministry of Information and Broadcasting, Government of India.

Gaventa, J. (2003). Finding the spaces for change: a power analysis. IDS bulletin, 37(6), 23-33.

Gee, J. P. (2004). Discourse analysis: What makes it critical. In An introduction to critical discourse analysis in education (pp. 49-80). Routledge.

Gramsci A. (1971). Selections from Prison Notebooks. London: Lawrence and Wishart.

Hunting, G., et al. (2015). Taking action on stigma and discrimination: An intersectionality-informed model of social inclusion and exclusion. Intersectionalities: A Global Journal of Social Work Analysis, Research, Polity, and Practice, 4(2), 101-125. 
Lazo, L. (1993). Women, education and empowerment: pathways towards autonomy. In Some reflections on the empowerment of women, (Ed.) (pp.238-252) UNESCO Institute for education. Hamburg.

Mandal, K. C. (2013, May). Concept and Types of Women Empowerment. In International Forum of Teaching \& Studies (9) 2. 27-38

Pathak, K.N., \& Tomar, J.S. (2012). Skill-Upgradation in five-year plans. Yojana, August 2012, Ministry of Information and Broadcasting, New Delhi.

Patel, A. (2012). Improving performance of rural health services. Kurukshetra, a Monthly Journal on Rural Development, New Delhi.

Podesva, R. J. \& Sharma D. (2012). Research methods in linguistics. New York: CPU.

Rao, P. \& Sethumadhav H. (2001). Education for women's empowerment. In Promilla Kapur (Ed.), Empowering the Indian Women (pp.428-441). Publications Division, Ministry of Information and Broadcasting, Government of India, New Delhi.

Sinaga, M. P. P. (2018). the ideology of women empowerment in malala yousafzai's speeches: a critical discourse analysis. Yogyakarta: Universitas Sanata Dharma.

Sipra, M., \& Rashid, A. (2013). Critical Discourse Analysis of Martin Luther King’s Speech in Socio-Political Perspective.

Srivastava, R.S. (2001). Women empowerment: Some critical issue. In Abha Avasti and A.K. Srivastava (Eds.), Modernity, Feminism and Women Empowerment (pp.213-227). Rawat Publications, New Delhi.

UNESCO \& UNICEF. (2010). Achieving gender equality, women's empowerment and strengthening development co-operation. In Women's and girl's education: A development imperative, (Ed.). Department of economic and social affair. New York: US.

United Nations. (2015). Declaration of human right. United Nations.

Van Dijk, TA. (1993). Elite discourse and racism. London: Sage Publications.

Van Dijk, T.A. (2008). Discourse and context: A socio-cognitive approach. Cambridge University Press: Barcelona.

Wetherell, M. (2001). Debates in discourse research. In M. Wetherell, S. Taylor, \& S. J. Yates (Eds.), Discourse theory andpractice: A reader (pp. 380-399). London: Sage

Wodak, R.\& M. Meyer (1996). (Ed.). Methods of critical discourse analysis. London - Thousand Oaks - New Delhi: SagePublications.

Wodak, R. \& Chilton, P. (2005). New agenda in (critical) discourse analysis. London: SAGE Pub. Inc.

Yousafzai, M. (2020). Education first. In M. S. Saud (writer), English Grade 11. Sanothimi, Bhaktapur: Curriculum Development Centre. 